\title{
Law Enforcement against Entrepreneurs who Conduct Criminal Acts to Pay Wages Under the Minimum Wage
}

\author{
Sekar Tresna Raras Tywi ${ }^{*}$, Ira Alia Maerani ${ }^{* *}$ and Arpangi ${ }^{* * *}$ ) \\ *) Student of Master of Law, Universitas Islam Sultan Agung Semarang, E-mail: \\ rarasdhita25@gmail.com \\ **) Lecturer of Master of Law, Universitas Islam Sultan Agung (UNISSULA) Semarang \\ ${ }^{* * *}$ Lecturer of Master of Law, Universitas Islam Sultan Agung (UNISSULA) Semarang
}

\begin{abstract}
This study aims to determine how law enforcement is carried out by labor inspectors against employers who pay wages lower than the minimum wage. The method used in this paper is sociological juridical. The conclusion of this paper is that law enforcement on the payment of wages below the minimum wage is carried out gradually through preventive educational efforts, repressive nonyustisia to repressive yustisia. It is hoped that through this process the employer can pay the lowest wage according to the minimum wage so that punishment is the last alternative (ultimum remedium).

Keywords: Law Enforcement; Minimum Wages; Labor Inspectors.
\end{abstract}

\section{Introduction}

Wages are the most important thing in employment, because the purpose of working people is to get wages that will be used to meet their daily needs. One form of State protection for workers' wage protection is the stipulation of a Minimum Wage which aims as a safety net ${ }^{1}$ so that labor wages do not decline.

The regulation regarding the obligation of employers to pay wages according to the minimum wage is regulated in Article 90 paragraph (1) of Act No. 13 of 2003 concerning Manpower which has been revoked and re-regulated under Article 81 paragraph (25) of Act No. 11 of 2020 concerning Job Creation, namely Article 88 letter E paragraph (2), that "Entrepreneurs are prohibited from paying wages lower than the minimum wage". Violation of these provisions is a form of crime. Sanctions on the provisions of the minimum wage payment are regulated inArticle 185 Act No. 13 of 2003 concerning Manpower which has been amended by Article 81 paragraph (63) of Act No. 11 of 2020 concerning Job Creation is regulated regarding sanctions, that(1). Anyone who violates the provisions (one of which is Article $88 \mathrm{E}$ paragraph (2)) is subject to imprisonment for a minimum of 1 (one) year and a maximum of 4 (four) years and/or a fine of at least IDR 100,000,000.00 (one hundred million rupiahs) and a maximum of IDR 400,000,000.00 (four hundred million rupiahs).

Although there have been regulations regarding the prohibition of paying wages below the minimum wage and have been accompanied by criminal threats for violators, there are still many employers who still pay wages lower than the minimum wage. The operation of the law is always limited by a situation of incompatibility between what

\footnotetext{
${ }^{1}$ Ahmad Rahmat, dkk. (2020). Problematika Hukum Perburuhan di Indonesia. Gowa: Jariah Publishing Intermedia. p. 9.
} 
should be (das sollen) and what is real (das sein). In other words, there is a discrepancy between law in the books and law in action. ${ }^{2}$

Law enforcement is a process to make what is aspired in legislation into reality. Employment of labor inspectors will enforce laws and regulations in the field of manpower. This includes law enforcement against employers who pay wages below the minimum wage.

Based on the description above, this research wants to answer the question about how the provisions of the crime of paying wages below the minimum wage and how is the law enforcement by labor inspectors against employers who pay workers wages below the minimum wage.

\section{Research Methods}

The research method used in this writing is the Sociological Juridical method. The type of research in this research is juridical empirical which in other words is a type of sociological legal research and can also be called field research, which examines the applicable legal provisions and what happens in reality in society. ${ }^{3}$ Or in other words, namely a research conducted on the actual situation or real conditions that occur in society with the intention of knowing and finding the facts and data needed, after the required data is collected then it leads to problem identification which ultimately leads to problem solving. ${ }^{4}$

\section{Results and Discussion}

\subsection{The Crime of Paying Wages below the Minimum Wage}

The term criminal offense comes from a term known in Dutch criminal law, namely strafbaarfeit ${ }^{5}$. A criminal act, also called a criminal event, is a punishable act.

Criminal acts are contained in the systematics of the Criminal Code. The second book contains criminal acts and the third book contains criminal offenses. Crime is an act based on the quality or nature of the disgraceful act. Meanwhile, a violation is an act that is considered a despicable act as a criminal act solely because it is regulated in law ${ }^{6}$.

The law must be strengthened by punishment/punishment/sanction. Sanctions to strengthen legal norms by means of criminal sanctions are the last bastion. So that the application of criminal law is the last step if all efforts have been made but cannot overcome it or it is known as the ultimum remedium. ${ }^{7}$

\footnotetext{
${ }^{2}$ Esmi Warassih. (2016). Pranata Hukum Sebuah Telaah Sosiologis. Semarang: Cetakan Kedua. Badan Penerbit Universitas Diponegoro. p. 65

3 Bambang Waluyo. (2002). Penelitian Hukum Dalam Praktek. Jakarta: Sinar Grafika. p. 15.

4 Ibid. p. 16

${ }^{5}$ Fitriyani. (2020). Tindak Pidana Khusus. Medan: Enam Media. P. 1

${ }^{6}$ Anton Susanto, Ira Alia Maerani, Maryanto, Legal Enforcement by the Police against Child of Criminal Doer of a Traffic Accident Who Caused Death (Case Study in Traffic Accident of Police Traffic Unit of Cirebon City Police Juridiction), Jurnal Daulat Hukum Vol. 3 No. 1 (2020), url : http://jurnal.unissula.ac.id/index.php/RH/article/view/8402/3928.

${ }^{7}$ Rahman Amin. (2019). Pengantar Hukum Indonesia. Yogyakarta: Deepublish. p. 143.
} 
There are several theories regarding the purpose of the punishment (the purpose of punishment), namely:

- Absolute Theory or Vergeldings Theorieen (Retaliation); Regarding this absolute theory, Muladi and Barda Nawawi Arief stated the following: "Crime is an absolute consequence that must exist as a retaliation against the person who commits a crime, so the basis of justification for the crime lies in the existence or occurrence of the crime itself." ${ }^{8}$

- Relative Theory or Doel Theorieen (Purpose and Objectives); To provide a clearer picture of this relative theory Muladidan Barda Nawawi Arief gave the following opinion: "Crime is not just for retaliating or rewarding people who have committed a criminal act but has certain useful purposes, therefore this theory is often referred to as (Utilitarian Theory) so the basis for justifying the existence of crime according to this theory lies in its purpose, the sentence imposed is not "quia peccatum est" (because people make crimes) but $\mathrm{Ne}$ Peccetur (so that people do not commit crimes "9

- Combined Theory; According to the teaching of this theory, the legal basis for punishment lies in the crime itself, namely retribution or torture, but in addition to that, it is also recognized that the basis for punishment is the goal of the law. Satochid Kartanegara stated: ${ }^{10}$ "This theory is a reaction from the previous theory which cannot satisfactorily answer the nature of the purpose of punishment. According to the teachings of this theory, the legal basis for punishment lies in the crime itself, namely retribution or torture, but in addition to that, it is also recognized that the basis for punishment is the goal of the law."

- Rehabilitation Theory; According to the rehabilitative theory, "criminal behavior" is: "... the consequence of influences over which individual offenders lack any meaningful degree of control." So the perpetrator of a crime is described as someone who is drawn or moved to commit a crime by a force outside his free will (free choice) $^{11}$

Thus the objective of punishment according to this theory is: "... the objective of treating the offender rather than to punish with the objective either of giving the offender his or her just desert (that is, following a retributive theory) or of seeking to prevent crime through such mechanisms as defference and in capacitation (in the worst, following a utilization theory. ${ }^{12}$

The problem of wages is a problem most often raised by workers, especially during international labor days (May Day). The problem of wages can result in disharmony of relations between workers and employers and even to the realm of crime.

\footnotetext{
${ }^{8}$ Muladi dan Barda Nawawi Arief. (1984). Teori-Teori dan Kebijakan Pidana. Bandung: Alumni. p. 10

9 Ibid, p. 16

${ }^{10}$ Satochid Kartanegara. (1998). Hukum Pidana Bagian Satu. Jakarta: Balai Lektur Mahasiswa. p. 56

${ }^{11}$ Topo Santoso. (2016). Asas-Asas Hukum Pidana Islam. Jakarta: PT. Rajagrafindo Persada. p. 26 dikutip dari Thomas and Bishop, Rehabilitative Theor., p. 82.

12 Ira Alia Maerani. (2018). Hukum Pidana dan Pidana Mati. Semarang: Unissula Press. p. 118.
} 
Based on Article 88 letter E paragraph (2) of Act No. 11 of 2020 concerning Job Creation, it is stipulated that "Employers are prohibited from paying wages lower than the minimum wage. The meaning of entrepreneur, namely ${ }^{13}$ :

- Individuals, associations, or legal entities that run their own company;

- an individual, an association, or a legal entity that independently runs a company that does not belong to him;

- Individuals, associations, or legal entities that are in Indonesia representing companies as referred to in letters $a$ and $b$ which are domiciled outside the territory of Indonesia.

In Article 25 of Act No. 11 of 2020 concerning Job Creation is regulated regarding the exemption of minimum wage service by employers, namely in article 90 letter B of the Manpower Act, as follows:

- The minimum wage provision is exempted for micro and small businesses

- Wages for micro and small enterprises are applied based on an agreement between the employer and the worker

- The wage agreement in question is at least a certain percentage of the average public consumption based on data sourced from the authorized institution in the field of statistics.

- Wage provisions for micro and small businesses are regulated in a Government Regulation.

If an entrepreneur or anyone violates it, it is legally and convincingly proven to have committed a criminal act of paying a wage lower than the minimum wage, a criminal sanction may be imposed as regulated in Article 185 Act No. 13 of 2003 concerning Manpower which has been amended by Article 81 paragraph (63) of Act No. 11 of 2020 concerning Job Creation.

"Anyone who violates the provisions (one of which is Article $88 \mathrm{E}$ paragraph (2)) is subject to imprisonment for a minimum of 1 (one) year and a maximum of 4 (four) years and/or a fine of at least Rp 100,000,000.00 (one hundred million. rupiah) and a maximum of IDR 400,000,000.00 (four hundred million rupiahs").

The Manpower Act must fulfill the principles of balance and legal protection outlined in the Outline of the Nation State in order to achieve prosperity, justice and social welfare based on Pancasila and the 1945 Constitution ${ }^{14}$

In the opinion of the author, seen from the main purpose of punishment, Article 185 Act No. 13 of 2003 concerning Manpower which has been amended by Article 81 paragraph (63) of Act No. 11/2020 concerning Job Creation cannot achieve the objectives of punishment as in absolute, relative, combined, or rehabilitation theories.

Because in reality the payment of wages below the minimum wage by employers to workers is a matter of compulsion due to company profits that have not been able to pay labor costs as the wages set by the government.

The influence given to the wage policy can be seen based on the results of research conducted by Asep Suryahadi, that the increase in the minimum wage reduces labor

\footnotetext{
${ }^{13}$ Article 1 point 5 of Act No. 13 of 2003 concerning Manpower

${ }^{14}$ Metry Widya Pangestika, Arpangi, Implementation of Labor Overtime Protection of PT Hwaseung Indonesia, Law Development Journal, Volume 2 No 2, 2020, url: http://jurnal.unissula.ac.id/index.php/ldj/article/view/11474/4537
} 
absorption, for every $10 \%$ increase in wages will result in more than $1 \%$ of unemployment. The results of other research conducted by Devanto Pratomo show that for every increase in wages a minimum of $10 \%$ will reduce labor absorption by $4 \%$. Furthermore, Asep Suryahadi stated that every $10 \%$ increase in the minimum wage will result in a $10 \%$ increase in employment for white collar workers. This fact shows that the increase in the minimum wage is beneficial for white collar workers. Termination of employment by employers on the basis of high wages will encourage workers to seek work in the informal sector, resulting in an excess supply of labor in the informal sector. This excess will depress wages in the informal sector ${ }^{15}$.

According to Abdullah Sulaiman, the main consideration in determining the minimum wage is adequacy to meet the minimum living needs of workers, as well as the purchasing power of wage income to meet the necessities of life without sacrificing the company's financial capacity. And don't let the minimum wage adjustment result in company bankruptcy which can lead to layoffs ${ }^{16}$.

Apart from that, with regard to the minimum punishment of 1 (one) year and/or fines imposed on the perpetrator of the crime of paying wages below the minimum wage, which ultimately goes to the state treasury does not benefit the victim, in this case the worker, so that it has the potential to terminate business activities that impact on the occurrence of termination of employment.

\subsection{Law Enforcement by Labor Inspectors against the Crime of Paying Wages below the Minimum Wages}

Satjipto Rahardjo stated that the law cannot stand alone, meaning that the law cannot fulfill its hopes which are stated in the law. Therefore, law enforcement is an effort to realize the ideas contained in law, including the enforcement of criminal law as a form of protection for life, property and honor. ${ }^{17}$

Law enforcement against compliance with laws and regulations in the manpower sector is carried out by the Labor Inspector. This is in accordance with what is stipulated in Article 176 of Act No. 13 of 2003 concerning Manpower that "Labor inspection is carried out by competent and independent labor inspectors to ensure the implementation of labor laws and regulations".

The meaning of labor inspector employees, as stipulated in Article 1 paragraph (10) of the Regulation of the Minister of Manpower of the Republic of Indonesia No. 33 of 2026 concerning Labor Inspection Procedures is "Civil Servants who are appointed and assigned to functional positions of Labor Inspectors to supervise and enforce the implementation of laws and regulations in the field of manpower", while labor inspection activities are regulated in Article 1 paragraph 9 of the Regulation of the Minister of Manpower of the Republic of Indonesia. No. 33 of 2026 concerning Labor

\footnotetext{
${ }^{15}$ Sayd Mohammad Rifqi Noval. (2017). Hukum Ketenagakerjaan Hakikat Cita Keadilan dalam Sistem Ketenagakerjaan. Bandung: Refika Aditama. p. 276.

${ }^{16}$ Abdullah Sulaiman. (2008). Upah Buruh di Indonesia. Jakarta: Universitas Trisakti. p. 182.

17 I Putu Angga Feriyana, Anis Mashdurohatun, Arpangi, Development Of The Criminal Justice System: Initiating LPSK As A Criminal Justice Subsystem In Indonesia, Jurnal Daulat Hukum Vol. 3 No. 1 (2020), url : http://jurnal.unissula.ac.id/index.php/RH/article/view/8386/4060.
} 
Inspection Procedures, namely activities to supervise and enforce the implementation of laws and regulations in the manpower sector. Based on Act No. 23 of 2014 concerning Regional Government, labor inspection becomes the authority of the province under the auspices of the Governor.

In general, the understanding of supervision according to the experts as quoted by Rahardjo includes: ${ }^{18}$ :

- Victor M Situmorang and Jusuf Juhir stated that supervision is every effort and action in order to know the extent to which the implementation of the task is carried out according to the provisions and objectives to be achieved.

- Sondang P Siagian defines supervision as the process of observing the implementation of all organizational activities to ensure that all work being carried out goes according to a predetermined plan.

- Djamaludin Tanjung and Supardan put forward the notion of supervision, which is a management function to ensure that work is carried out in accordance with the standards set in the planning.

Whereas specifically, labor inspection is a public function of labor administration that ensures the application of labor laws in the workplace. ${ }^{19}$

Labor inspection employees are competent and independent, meaning that labor inspection employees must understand labor and must not take sides with one party, and in making decisions are not influenced by other parties.

Inspection instruments in the political scheme of labor law, supervision can be a framework for law enforcers to observe, analyze, and assess factual conditions in the field. Supervision is the doorway for further law enforcement processes, whether in the form of an administrative process which may lead to the imposition of administrative sanctions against companies deemed to have committed violations, or as a basis for conducting investigations against companies if they are deemed to have committed violations that fall within the criminal domain.

The objectives of the Labor Inspection as stipulated in Article 3 of the Minister of Manpower Regulation No. 33 of 2016 concerning Labor Inspection Procedures, namely to ensure the implementation of Labor Norms in Companies or Workplaces. Meanwhile, the function of the labor inspection is ${ }^{20}$ :

- guaranteeing labor law enforcement;

- provide information and technical advice to Entrepreneurs and Workers/Laborers on matters that can guarantee the effectiveness of the implementation of manpower legislation; and

- collect information regarding work relations and conditions of employment in the broadest sense as material for preparation or improvement.

\footnotetext{
18 Rahardjo Adisasmita. (2011). Pengelolaan Pendapatan dan Anggaran Daerah. Yogyakarta: Graha Ilmu. p. 45.

19 Widodo Suryondono. (2017). Tenaga Kerja Asing: Analisis Politik Hukum. Jakarta: Yayasan Pustaka Obor Indonesia. p. 114

${ }^{20}$ Article 3 of the Minister of Manpower Regulation No. 33 of 2016 concerning Labor Inspection Procedures
} 
According to Liliana Tedjosaputro, law enforcement does not only include law enforcement, but also peace maintenance ${ }^{21}$. In the field of Manpower, law enforcement is carried out by the Labor Inspector including the following actions:

\subsubsection{Educational Preventive}

It is a coaching activity as a preventive effort through the dissemination of Labor Norms, technical advice, and assistance. Coachingaimed to to improve compliance with Labor Norms, and carried out through technical advisory activities, outreach, training, consultation meetings, discussions and assistance, for example through socialization to the Indonesian Employers Association regarding the philosophy of the minimum wage, the obligation to pay wages according to the minimum wage and sanctions for violations of minimum wage provisions.

\subsubsection{Repressive Non Yustisia (Labor Examination).}

It is a forced attempt outside a court institution to comply with the provisions of labor laws and regulations in the form of an Audit Note as a warning or a statement letter of the ability to comply with labor laws and regulations.

Labor Inspection, hereinafter referred to as Inspection, is a series of activities carried out by the Labor Inspector to ensure compliance with the implementation of labor laws and regulations in the Company or the Workplace.

After carrying out an inspection, each Labor Inspector is obliged to make an Audit Memorandum. There are 2 types of examination notes for the crime of paying wages below the minimum wage, namely:

- Audit Note I;

- Inspection Note II;

Audit Note I is made within a maximum period of 3 (three) working days from the completion of the Audit Note and the period for implementing the Audit Note I is given an appropriate and reasonable time limit of 30 (thirty) days from the receipt of the Audit Note I. If the Audit Note I is not carried out within the predetermined time limit, the Labor Inspector conducting the Audit is obliged to issue the Audit Note II.

Audit Note II shall be given an appropriate and reasonable time limit no later than 14 (fourteen) days after receipt of Audit Note II. If the Inspection Note II is not carried out by the Entrepreneur, the Labor Inspector conducting the Audit reports to the Head of the Labor Inspection Work Unit. The Head of the Labor Inspection Work Unit after receiving the report takes the following actions:

- order to carry out an investigative action, in the case of non-compliance which is subject to criminal sanctions;

- take legal action in accordance with the authorities stipulated in statutory regulations; and

- issue recommendations to authorized officials to take legal action in accordance with statutory regulations

\subsubsection{Repressive Justisia (Investigation)}

\footnotetext{
${ }^{21}$ H. Salle. (2020). Sistem Hukum da Penegakan Hukum. Makassar: CV. SocialPolitic Genius. p. 79.
} 
Justisial repressive action is the last alternative and is carried out through the judiciary. This effort is taken when the Supervisory Officer has provided guidance and provided a warning, but the entrepreneur still does not heed the purpose of the guidance. This is in accordance with the principle contained in Indonesian criminal law which states that criminal law should be used as a last resort in terms of law enforcement (Ultimum Remedium). Thus, Supervisory Staff as Civil Servant Investigators (PPNS) are obliged to carry out investigations and follow up in accordance with applicable legal procedures. The meaning of special employment investigation in Article 1 paragraph (17) of the Regulation of the Minister of Manpower of the Republic of Indonesia No. 33 of 2016 concerning Labor Inspection Procedures, it is explained that "Investigation of Labor Criminal Acts is a series of PPNS Ketenagakerjaan actions in terms and according to the manner stipulated in the Criminal Procedure Code to seek and collect evidence which with that evidence sheds light on labor crimes that have occurred in order to find the suspect. "22.

The authority of Manpower Civil Servant Investigators as regulated in Article 182 paragraph (2) of Act No. 13 of 2003 concerning Manpower are as follows ${ }^{23}$ :

- conduct examination of the correctness of reports and information on criminal acts in the manpower sector;

- conduct examination of persons suspected of committing criminal offenses in the manpower sector;

- request information and evidence from a person or legal entity in connection with a crime in the manpower sector;

- conduct examination or confiscation of material or evidence in a criminal case in the manpower sector;

- conduct examination of letters and/or other documents concerning criminal acts in the manpower sector;

- requesting assistance from experts in the context of carrying out the task of investigating criminal acts in the manpower sector; and

- stop an investigation if there is insufficient evidence that proves the existence of a crime in the manpower sector.

Certainty/law enforcement must continue to prioritize justice, as well as in its handling criminal cases ${ }^{24}$

Labor law enforcement related to the payment of wages below the minimum wage which goes through a long series of processes starting from preventive educational activities, non-justisia repressive actions through labor inspections and the issuance of an Audit Note whether it is completed with the issuance of an Audit Note I or up to an Audit Note II is an effort to provide tolerance for Entrepreneurs. in order to comply with the provisions stipulated in the laws and regulations in the manpower sector in stages so that business activities can still run and minimize termination of employment. Meanwhile, yustisia's repressive action through a judicial mechanism is the last step if the entrepreneur does not have good faith in the effort to fulfill the

\footnotetext{
${ }^{22}$ Article 1 paragraph (17) of the Regulation of the Minister of Manpower of the Republic of Indonesia No. 33 of 2016 concerning Labor Inspection Procedures

${ }^{23}$ Article 182 paragraph (2) of Act No. 13 of 2003 concerning Manpower

${ }^{24}$ Anton Susanto, Ira Alia Maerani, Maryanto, op cit
} 
provisions of laws and regulations in the field of manpower related to minimum wages.

\section{Closing}

The provisions for the crime of paying the minimum wage are regulated in Article 185 Act No. 13 of 2003 concerning Manpower which has been amended by Article 81 paragraph (63) of Act No. 11 of 2020 concerning Job Creation.The criminal act is a criminal offense and can be subject to imprisonment for a minimum of 1 (one) year and a maximum of 4 (four) years and/or a fine of at least IDR 100,000,000 (one hundred million rupiah) and a maximum of IDR 400,000. 000.00 (four hundred million rupiah"). Law enforcement of the criminal act of paying workers wages below the minimum wage through a series of processes as regulated in the Minister of Manpower Regulation No. 33 of 2016 concerning Labor Inspection Procedures in its implementation is not only based on the principle of legal certainty but also adheres to the principles of justice and benefit.

Furthermore, it is suggested that the regulation of criminal sanctions against employers who pay wages below the minimum wage so that revisions are made, because a minimum sentence of 1 (one) year and/or a fine that ultimately goes to the state treasury does not benefit the victim, in this case the worker, it has the potential to terminate business activities which will result in termination of employment and will ultimately hinder the country's goal of realizing welfare social. Law enforcement against employers who pay wages below, apart from being carried out according to the procedures set out inMinister of Manpower Regulation No. 33 of 2016 concerning Labor Inspection Procedures, so that the rights of underpayment of the minimum wage can be resolved in accordance with the procedures for settling industrial relations disputes.

\section{References}

\section{Journals:}

[1] Anton Susanto, Ira Alia Maerani, Maryanto, Legal Enforcement by the Police against Child of Criminal Doer of a Traffic Accident Who Caused Death (Case Study in Traffic Accident of Police Traffic Unit of Cirebon City Police Juridiction), Jurnal Daulat Hukum Vol. 3 No. 1 (2020), url : http://jurnal.unissula.ac.id/index.php/RH/article/view/8402/3928.

[2] I Putu Angga Feriyana, Anis Mashdurohatun, Arpangi, Development of The Criminal Justice System: Initiating LPSK As A Criminal Justice Subsystem In Indonesia, Jurnal Daulat Hukum Vol. 3 No. 1 (2020), url : http://jurnal.unissula.ac.id/index.php/RH/article/view/8386/4060.

[3] Metry Widya Pangestika, Arpangi, Implementation of Labor Overtime Protection of PT Hwaseung Indonesia, Law Development Journal, Volume 2 No 2, 2020, url: http://jurnal.unissula.ac.id/index.php/ldj/article/view/11474/4537.

\section{Books:}

[1] Abdullah Sulaiman. (2008). Upah Buruh di Indonesia. Jakarta: Universitas Trisakti. 
[2] Ahmad Rahmat, dkk. (2020). Problematika Hukum Perburuhan di Indonesia. Gowa: Jariah Publishing Intermedia.

[3] Bambang Waluyo. (2002). Penelitian Hukum Dalam Praktek. Jakarta: Sinar Grafika.

[4] Esmi Warassih. (2016). Pranata Hukum Sebuah Telaah Sosiologis. Semarang: Cetakan Kedua. Badan Penerbit Universitas Diponegoro.

[5] Fitriyani. (2020). Tindak Pidana Khusus. Medan: Enam Media.

[6] H. Salle. (2020). Sistem Hukum da Penegakan Hukum. Makassar: CV. SocialPolitic Genius.

[7] Ira Alia Maerani. (2018). Hukum Pidana dan Pidana Mati. Semarang: Unissula Press.

[8] Muladi dan Barda Nawawi Arief. (1984). Teori-Teori dan Kebijakan Pidana. Bandung: Alumni.

[9] Rahardjo Adisasmita. (2011). Pengelolaan Pendapatan dan Anggaran Daerah. Yogyakarta: Graha Ilmu.

[10] Rahman Amin. (2019). Pengantar Hukum Indonesia. Yogyakarta: Deepublish.

[11] Satochid Kartanegara. (1998). Hukum Pidana Bagian Satu. Jakarta: Balai Lektur Mahasiswa.

[12] Sayd Mohammad Rifqi Noval. (2017). Hukum Ketenagakerjaan Hakikat Cita Keadilan dalam Sistem Ketenagakerjaan. Bandung: Refika Aditama.

[13] Topo Santoso. (2016). Asas-Asas Hukum Pidana Islam. Jakarta: PT. Rajagrafindo Persada.

[14] Widodo Suryondono. (2017). Tenaga Kerja Asing: Analisis Politik Hukum. Jakarta: Yayasan Pustaka Obor Indonesia.

\section{Regulation:}

[1] Act No. 13 of 2003 concerning Manpower

[2] Act No. 23 of 2014 concerning Regional Government

[3] Act No. 11 of 2020 About Job Creation

[4] Government Regulation No. 78 of 2015 concerning Wages

[5] Regulation of the Minister of Manpower of the Republic of Indonesia No. 33 of 2016 concerning Labor Inspection Procedures 